\title{
MEDIA SOCIALIZATION OF INDIVIDUALS IN MODERN INFORMATIONAL SOCIETY
}

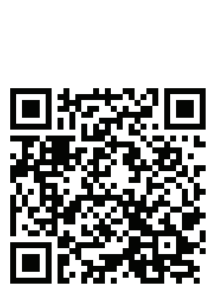

To cite this article:

\author{
Sergii Savchenko, Dr. Sc., Prof. \\ Rector, Taras Shevchenko Luhansk National University, \\ Luhansk, Ukraine \\ savsevik@gmail.com \\ https://orcid.org/0000-0003-4118-6756 \\ Vitalii Kurylo, Dr. Sc., Prof. \\ President, Taras Shevchenko Luhansk National University, \\ Luhansk, Ukraine \\ donluga@gmail.com \\ https://orcid.org/0000-0003-2471-3358
}

\author{
Savchenko, S. \& Kurylo, V. (2018). Media socialization \\ of individuals in modern informational society. \\ Education: Modern Discourses, 1, 174-183. \\ https://doi.org/10.32405/2617-3107-2018-1-17
}

\begin{abstract}
The article deals with the analysis of the essential characteristics of media socialization of individuals in the informational society. Based on the theoretical analysis held, the author arrives at the conclusion that media socialization is a topical aspect of the social development of individuals in the social and cultural space of the informational society and is an important component of the modern process of individuals' socialization. In conditions of modern challenges there increases scholars' attention to the problems of youths' socialization-young men being at the stage of the development of their personalities as future professional, they being engaged in the virtual reality of the modern social and cultural space. In this context, it is hard to overestimate the role of institutions of higher education as the leading agents of a socially controlled socialization of individuals in modern social and cultural environment.
\end{abstract}

Key words: agents of socializations; individuals; informational society; media socialization; social and cultural space.

\section{INTRODUCTION. PROBLEM STATEMENT}

One of the most important challenges of the modern theory of socialization is connected with the definition and classification of different institutions of socialization that, depending on their nature, essential characteristics, and peculiarities of their influence on an individual, are referred to different classification structures by different scholars. An additional confusion is caused by the absence of a commonly used terminological foundation for their description. In different sources, they are defined and referred to as agents of socialization, factors, kinds, types, directions, mechanisms, etc. Without going deep into the analysis of which of the terms is more precise and can clearly reflect the core of the notions, it is still worth mentioning that all of them, to a certain extent, recreate the essential characteristics of the phenomenon of socialization.

Analysing socialization in the social and cultural space of the informational soci- 
ety, our attention should be paid to the factors of socialization, which define the directions of the social and pedagogical activity towards socialization of a certain social group. Ukrainian and foreign scholars tend to subdivide them into the following groups, namely, mega-factors (space, our planet, the world); macro-factors (country, ethnos, society, state, culture); meso-factors (type of dwelling); micro-factors (formal ones: educational establishments and organizations, cultural institutions, etc.; informal ones: family, neighbors, peers, etc.) (Mudrik, 2006; Zelenov \& Stiopina, 2010, etc.).

In this context, following the works by Anderson, Genner \& Süss, Lemish, Livingstone, Prensky and others, we would like to add media as another important mega-factor of socialization in the modern informational society.

\section{LITERATURE REVIEW}

Modern scientific research (Hobbs, 2010; Lebo, 2013; Simpson, 2001; Romanova, 2004; Kirillova 2006; Sheiko, 2011; Stepanov, 2010; Burakova, 2010, etc.) define the following mechanisms of socialization: identification (authentication of an individual with other people, groups, communities which predetermines an efficient acquisition of norms of behaviour inherent in the surrounding environment); imitation (reproducing certain examples of behaviour and activities of others by an individual); imprinting (fixation of an individual on receptor and subconscious levels of peculiarities of objects that influence him); reflection (evaluating his own different selves by a personality); exteriorization (a process of transformation of external, real operations of social activity to the internal and ideal ones); exteriorization (a process of transfer from the internal, mental activity to the external, practical one); social facilitation (increasing and stimulating the acquired norms in the presence of others). Generalizing the existing approaches to the classification of the mechanisms of socialization, A. Mudryk divides them into the following groups: traditional ones (an unconscious acquisition by an individual of the norms and examples of behaviour, viewpoints, values, stereotypes characteristic of the nearest environment (family, neighbours, relatives, friends, etc.); institutional ones (acquiring social experience and culture during the person's interaction with the institutions of the society and different organizations including mass media); conventionalized ones (acquiring standards of behaviour, norms and values of a separate subculture, people of a certain age, profession, national or social group which in combination influences the style of life and thinking of an individual); interpersonal ones (a process of interaction of an individual with influential (authoritative) for him personalities); reflexive ones (inner dialogues an individual's different selves with real or unreal (imaginary) persons that takes place when the person is alone) (Mudrik, 2006: p. 40-41).

These mechanisms contribute to the efficient solution of the tasks of socialization of individuals, namely, the natural and cultural ones, the social and cultural ones, the social and psychological ones (Soshcheko, 2007: p. 7-8).

The influence of a virtual reality on the process of socialization of individuals has been in the centre of scientific interests of a great many of Ukrainian and foreign scholars (see the works by Bennett, Maton, \& Kervin, Deters \& Mehl, Hargittai, Kirsh, Cheremisin, Danilova, Zhilkin, etc.).

The reasons and consequences of the change of human mind in the informational society and in the social and cultural space of the anthropogenic civilization have been 
studied by Livingstone, Palfrey \& Gasser, Przybylski, Murayama, DeHaan \& Gladwell, Stieger, Burger, Bohn \& Voracek, Sheiko, Maksymovska, Petrunko, Borodina, Lau, etc.).

Informational technologies in the social and cultural space have been investigated by Lebo, Meshi, Morawetz \& Heekeren, Smith, Choueiti \& Piepe, Turkle, Cheremisin, etc.

\section{MAIN RESULTS}

Information in the modern world has become one of the main values of any society whereas informational resources are becoming more available due to the rapid development of informational technologies. As the Russian scholar I. Soshchenko states, "a special value-based attitude to the information and to the knowledge and skills to create, store and render it as well as the accessibility of this value represent the main distinguishing feature of the informational society" (Soshchenko, 2007: p. 14).

Modern research focuses on the informational civilization with the meaning of the world's informational society. For instance, N. Kirillova defines the informational society as a new informational civilization, which is connected with "a tremendous, never seen before influence of modern industry of information practically on all the spheres of life and mind" (Kirillova, 2006: p. 294). The Ukrainian scholar V. Sheiko points out that "informational civilization is a qualitatively new social and political formation which has appeared as a substitution for the material (anthropogenic) civilization and which efficiently ensures the acquisition of the processes of informatization as an inevitable and universal period of the development of the society, the cognition and perception of the informational pattern of the universe as well as a general awareness and adoption of the unity of the laws of information in nature and society" (Sheiko, 2011: p. 201).

The main preconditions of the formation of the informational society are connected with the fact that information has obtained the meaning of the main social value and good, the transformation of informational products and services into the leading object of production and consumption that allows an individual receiving according to his own needs without any limits.

V. Sheiko emphasizes that "the real informational civilization has to provide every citizen of a society with such social conditions that will let him easily receive all the necessary information in order to solve most urgent problems in life in any place and at any time" (Sheiko, 2011: p. 201).

The significance of information for an individual is constantly growing. As the Ukrainian scholar V. Stepanov thinks, "informational society means a level of the development of the mankind at which informational products and services become the dominating objects of production and consumption whereas the traditional objects of consumption produced by industry and agriculture do not at all lose their importance for individuals, however in the process of production and exchange of consumer goods and services the portion of "the information intensive" operations and products starts to prevail” (Stepanov, 2010: p. 147).

Many scholars have attempted to define the criteria of the informational society among which they discriminate the following: 1) "knowledge cult" which means that an individual is evaluated according to what he knows and how he uses this knowledge; special attention is paid to meta-knowledge, i.e. knowledge of how to get knowledge and process it; 2) the national informational system and ensuring the citizens an access to the 
global informational network; 3) restructuring the labor resources (manpower) aimed at increasing the portion of the informational sector $(50 \%$ - the informational sector, $25 \%$ - industry and agriculture, $25 \%$ - services with a great part of the informational ones) (Burakova, 2010: p. 603).

We cannot but agree with the opinion of V. Sheiko that "in the modern world of the global civilizational transformations which have led to the formation of the informational society, culture plays the leading role which determines the current and future development of the mankind" (Sheiko, 2011: p. 200). Crucial transformations that are taking place in the modern society have revealed new challenges for culture that are connected with the increase of its role in the process of solution of most important problems of the informational society. These changes precondition the growth of the social and mental tension and significantly influence the social, psychological and cultural development of an individual whose role becomes rather important. Informational technologies make it possible to accelerate intercultural communication, going onto a qualitatively new level when in order to realize it, it is not necessary to cover distances (not even necessary to learn foreign language) - the cultural exchange between peoples takes place through the global networks being dynamic and sometimes uncontrolled, however a person can realize his needs in intercultural communication without leaving the house. Under such conditions, there appears a need to have mutual understanding between the representatives of different cultures, the bearers of different social values and behaviours.

Virtual space has become an obligatory component of the social existence of a modern individual. Due to modern informational technologies, a person in the virtual space easily covers distances, takes an active part in different discussions, feels strong and protected from the current events and the problems of the real life. He can put on different masks and play different roles at the same time feeling secure since the communication is arranged virtually and anonymously. Virtual space does not imply following any rules necessary during a real communication, thus it reduces the influence of such traditional institutions of socialization as Motherland, educational establishment, friends, etc. on an individual. Therefore, a completely new personality is formed who reveals his inner features preconditioned by the interaction of an individual and the social and cultural space of the informational society, by the necessity to gradually adapt to it. A person strives for diving into the virtual space trying to escape from everyday problems, stresses and fatigue so that he could experience only virtual emotions. Thus, informational technologies manage to change the way of interaction between an individual and the world: the former acquiring a great number of opportunities for the development and selfrealization. On the other hand, an individual comes across numerous risks connected, in particular, with mental insanity because having huge possibilities for self-realization, development of his own individuality in virtual space, a person does not only create his own virtual world but also becomes an object of informational aggressiveness and different manipulations facing the danger levelling his own personality. When a real personality tries to hide behind the images created by himself, it can result in a crisis of the self, in losing his cultural identity and can trigger off complications in exercising a real interpersonal communication. He can lose connection with the real world without being aware of it. Thus, there appears a change of values of real life for the values of the artificially created virtual world.

A particular danger of such a virtual reality is connected with the youth who have not yet formed their world outlook, the system of values and whose personal social quali- 
ties are still in the process of formation. In such conditions, representatives of the young generation can hardly find the correct ways of their own spiritual development and social realization. Life of modern young people undergoes significant changes under the influence of challenges of the informational society. Being the most active part of the population, young people constantly are engaged in different kinds of links in a society. Because of it there increases the number of stresses, and young people have to take a greater responsibility for their own life experiencing the burdens of uncertainty and socialization risks not typical for previous generations. Since these transformations take place rather dynamically, the young generation fails to adapt to them that results in increasing the uncertainty in the process of socialization of modern youth. At the same time, young people appear to be one of the less protected strata of the society; there is observed a worsening of their material conditions in modern social and cultural space let alone the possibilities for their social development and self-realization.

Virtualization of the modern space can be viewed upon as a social and cultural phenomenon which predetermines the main landmarks of the vital activity of a modern person because it is a virtual reality that opens wide horizons for an individual to realize the possibilities never seen before and to have a practically unlimited access to knowledge, exchange of information, establishment of interpersonal interaction.

In the space of virtual culture there appears a necessity to form new values which correspond to the demands of the virtual reality or, in other words, there takes place a transformation of the traditional values according to these needs provided that the main ones are preserved. Under the influence of modern informational technologies there is observed a change of social institutions and social processes; an individual is being engaged into a great number of social virtual communities; the flows of different information are being increased which results in growing the amount (volume) of information which can bring harm to the society and at the same time creative possibilities of individuals also increase.

Informational and communication technologies become preconditions for the formation of a new type of personality in accordance with the demands of the informational society: one of the main characteristics of a modern individual is connected with the development of the so-called global thinking that includes respect of different cultures, growth of interest to understand them, a positive perception of differences between cultures and the national peculiarities of every culture. Thus, a formation of cross-cultural literacy and intercultural competence of an individual as integral personal qualities of a young man connected with the awareness of the diversity of modern cultures and a positive attitude towards cultural differences becomes topical.

It is possible to conclude that the informatization of the modern social and cultural space in all the spheres of vital activity of an individual leads to certain contradictions among which are the following ones: on the one hand, having unlimited access to possibilities for the self-development and self-realization due to an unlimited access to different kinds of information via the extension of social and cultural cooperation can lead to the optimization of the creative process, however, on the other hand, the increase of numerous risks connected with the formation of stereotypes of mass consciousness, possibilities for manipulations, transformations of value orientations, aloofness of a personality can lead to aggression, a sense of impunity and lack of restraint.

Under the influence of globalization, there take place certain social transformations of the structures and institutions of socialization that change the logic of social develop- 
ment. Within the informational society, individuals enter the epoch of a global social and cultural space and a new type of people of a new social reality is formed. As a result of the global processes, the social interaction, the social being receive new features and qualities thus, making topical the problem of the dialogue of cultures for the social and cultural space of the informational society. In such circumstances of the civilization globalization, the need for dialogues of cultures with the preservation of the national and mental peculiarities of different peoples of the world is greatly increased (Sheiko, 2011: p. 278).

This context requires a greater attention to the problem of socialization in the social and cultural space of the informational society. We cannot but share the idea of the Ukrainian scholar B. Maksymovska that "information concurrently defines the social and cultural life of an individual as well as his material being which requires adequate mechanisms of a corresponding adjustment and harmonization of the social development of the subject of the society (Maksymovska, 2015: p. 109).

Hence, the theory of socialization has a significant meaning for studying the processes of an individual's formation in the social and cultural space of the informational society in which the extension of intercultural contacts makes it topical the problem of social upbringing and formation of cultural values of an individual.

Effects of media on socialization processes have traditionally focused on mass media such as television, radio, and printed media (books, newspapers, and magazines). Additionally, music and fan cultures around specific music groups or music genres have been the subject of research on media effects. The advent of a variety of digital and mobile media devices and the abundance of digital media content have transformed research on media effects correspondingly. Given the increasingly blurred lines between media producers and users ("producers") and between personal and public communication ("networked public sphere"), recent research in the field has largely focused on how digital media impact social behavior (Genner \& Süss, 2017).

It is true to state that for many, the smart-phone has indeed become a companion in any situation and most young users keep in constant touch with their friends via online communities and app-based messengers. Digital media use is more frequent among younger users, and generation is a major divide globally but also within countries. Studies have documented many differences in online behaviour among young Internet users - at a global level mainly geographical divides, and at a local level predominantly educational divides. In industrialized countries with a high Internet penetration, young users live in different milieus (especially regarding educational levels), have different approaches to the Internet, and have diverging attitudes regarding cyber-security and different levels of trust in online activities. Consequently media usage preferences are not only shaped by age and generation, but also by variables such as country of residence, educational levels, income, gender, personality, technical affinity, and cultural and ethnical background (Genner \& Süss, 2017).

Besides, socialization in the virtual space is predominantly spontaneous. An individual defines all by himself the way of his existence, behaviour, and means of communication in such a space; he lives a parallel life which can hardly be controlled by anybody else limiting his live communication in the real (non-virtual) life. As a result, a person loses links with the cultural traditions of his society, acquires norms, values, and rules not typical for a society in which he lives but for a network community in which he exists in the virtual reality which, in its turn, changes the individual's inner world, his attitude towards the surrounding reality and can lead to the crisis of cultural identity. 


\section{CONCLUSIONS}

We strongly believe that media socialization is a topical aspect of the social development of individuals in the social and cultural space of the informational society and is an important component of the modern process of individuals' socialization.

Summing up our analysis, we would like to emphasize that the methodological bases of studying socialization in the social and cultural space of the informational society include the following provisions: 1) the informational society in which the modern individual lives is characterized by an increase of the role of information and knowledge which receive the meaning of the main social value and product; informational products and services are transformed to be the key object of production and consumption; modern informational and communicational technologies make it possible for an individual to get unlimited information according to his own needs; 2) the transformations of the informational society have influenced the changes of the modern social and cultural space which should be viewed upon as a specific significate value that creates conditions an individual's efficient activity and enlarges his possibilities of choice of forms of self-realization in life in a society; 3 ) the modern social and cultural space is characterized by the following features: globalization of culture at all levels via the integration of national cultures into the world's one; universalization of cultural values which gives rise to the problem of co-existence of numerous national cultures, preservation of cultural identity; the increase of the role of dialogue of cultures in assertion of the common to the mankind value; the blur of borders of the modern social and cultural space; virtualization of the social and cultural space which opens new possibilities for communication and individuals' development and at the same time has a negative impact on their psychological states; 4) the modern social and cultural space changes the process of socialization - an individual's entering the society together with the social connections and integrations into different types of communities; the social environment significantly influences the formation of individuals and requires the creation of optimal conditions for the efficiency of the socialization process; 5 ) the changes that take place in the informational society have predetermined the following specific features of socialization, namely: the increase of the role of an individual with the simultaneous activation of the social and cultural processes in the society; the change of the role of factors of socialization, in particular it goes about the increase of the significance of mass media, strengthening of the influence of social communities which are being formed in the global network; the development of the virtual reality which is objectified through a person's activity, changes the channels of transmission of the social experience, transforms the socialization possibilities of individuals, ways of their creative self-realization.

In general, the process of media socialization as a component of individuals' socialization in the social and cultural space of the informational society is becoming topical: in conditions of modern challenges there increases scholars' attention to the problems of youths' socialization - young men being at the stage of the development of their personalities as future professional, they being engaged in the virtual reality of the modern social and cultural space. In this context, it is hard to overestimate the role of institutions of higher education as the leading agents of a socially controlled socialization of individuals in modern social and cultural environment. 


\section{REFERENCES}

Anderson, J. A. (2008). The production of media violence and aggression research: A cultural analysis. American Behavioral Scientist, 51 (8), 1260-1279. doi: 10.1177/0002764207312019.

Bandura, A. (1977). Social learning theory. Englewood Cliffs, NJ: Prentice Hall.

Bekker, I. L., Zhuravchik, V. N. (2009). Problema socializacii studencheskoj molodezhi v sovremennyh usloviyah [Problem of Socialization of Students in Modern Conditions]. Izvestiya Penzenskogo gosudarstvennogo pedagogicheskogo universiteta im. V. G. Belinskogo, 16, 141-151.

Bennett, S., Maton, K., \& Kervin, L. (2008). The "digital natives" debate: A critical review of the evidence. British Journal of Educational Technology, 39(5), 775-786. doi: 10.1111/j.14678535.2007.00793.x.

Borodina, V. A. (2004). Informacionnaya socializaciya - put'k vseobshchej dostupnosti informacii [Informational Socialization - a Way to General Access to Information]. Bibliotechnoe delo - 2004: vseobshchaya dostupnost' informacii: tez. dokl. 9-j mezhdunar. nauch. konf. M. S. 12.

Burakova, K. V. (2010). Analiz vahomykh skladovykh sotsialnoi adaptatsii inozemnykh studentiv do navchannia u vyshchykh navchalnykh zakladakh Ukrainy na pochatkovomu etapi [Analysis of Key Components of Social Adaptation of Foreign Students to Studying at Higher Educational Establishments at the Initial Stage]. Visnyk Luhanskoho natsionalnoho universytetu im. Tarasa Shevchenka, 7, 48-55.

Cheremisin, A. G. (2010). Konstruirovanie novoj social'noj i obrazovatel'noj real'nosti na osnove Internet-tekhnologij [Building New Social and Educational Reality on the Basis of InternetTechnologies] (PhD Thesis). Moskva.

Danilova, M. A. (2009). Internet-socializaciya studencheskoj molodezhi: specifika motivacii setevogo povedeniya [Internet Socialization of Students: specificity of motivation of network behavior] (PhD Thesis). Saratov.

Deters, F. G., \& Mehl, M. R. (2012). Does posting Facebook status updates increase or decrease loneliness? An online social networking experiment. Social Psychological and Personality Science, 4(5), 579-586. doi: 10.1177/1948550612469233.

Festinger, L. (1954). A theory of social comparison processes. Human Relations, 7(2), 117-140. doi: $10.1177 / 001872675400700202$.

Genner, S., Süss, D. (2017). Socialization as media effect. The International Encyclopedia of Media Effects. Retrieved from https://www.researchgate.net/publication/314395153_ Socialization_as_Media_Effect.

Hargittai, E. (2010). Digital na(t)ives? Variation in Internet skills and uses among members of the net generation. Sociological Inquiry, 80(1), 92-113. doi: 10.1111/j.1475-682x.2009.00317.x.

Hobbs, R. (2015). Media literacy. In D. Lemish, Children and media: A global perspective (pp. 417-424). Oxford, UK: Wiley Blackwell.

Hofstede, G., Hofstede, G. J., \& Minkov, M. (2010). Cultures and organizations: Software of the mind (3rd ed.). New York, NY: McGraw-Hill.

John, D. R. (1999). Consumer socialization of children: A retrospective look at twenty-five years of research. Journal of Consumer Research, 26(3), 183-213. doi: 10.1086/209559.

Kirillova, N. B. (2006). Mediakul'tura: ot moderna kpostmodernu [Media Culture: From Modern to Post-Modern]. Moskva: Akad. Proekt. (in Russian)

Kirsh, S. J. (2010). Media and youth: A developmental perspective. Oxford, UK: Wiley Blackwell. L'Engle, K. L., Brown, J. D., \& Kenneavy, K. (2006). The mass media are an important context 
for adolescents' sexual behavior. The Journal of Adolescent Health, 38(3), 186-192. doi: 10.1016/j.jadohealth.2005.03.020.

Lau, H. (2006). Rukovodstvo po informacionnoj gramotnosti dlya obrazovaniya na protyazhenii vsej zhizni [Guidance on Informational Literacy for Life-Time Education]. Moskva: IPO UNESCO WFP “Information for All”. (in Russian)

Lebo, H. (2013). The 2013 digital future report: Surveying the digital future: Year eleven. Center for the Digital Future, University of South Carolina Annenberg School for Communication. Retrieved from http://www.digitalcenter.org/wp-content/uploads/2013/06/2013-Report. pdf.

Lemish, D. (2015). Children and media: A global perspective. Oxford, UK: Wiley Blackwell.

Livingstone, S. (2009). On the mediation of everything: ICA Presidential Address 2008. Journal of Communication, 59(1), 1-18.

Maksymovska, N. O. (2015). Sotsialno-pedahohichna diialnist zi studentskoiu moloddiu u sferi dozvillia: animatsiinyi pidkhid: monohrafiia [Social and Pedagogical Activity with Students' Youth in Sphere of Leisure: Animation Approach: monograph]. Kharkiv : KhDAK. (in Ukrainian)

Meshi, D., Morawetz, C., \& Heekeren, H. R. (2013). Nucleus acumens response to gains in reputation for the self-relative to gains for others predicts social media use. Frontiers in Human Neuroscience, 7, 439.

Mudrik, A. V. (2006). Socializaciya cheloveka: uchebnoe posobie dlya studentov vysshih uchebnyh zavedenij [Socialization of a Man: manual for graduate students]. Moskva: Akademiya. (in Russian)

Palfrey, J., \& Gasser, U. (2008). Born digital: Understanding the first generation of digital natives. New York, NY: Basic Books.

Perlow, L. A. (2012). Sleeping with your smartphone: How to break the 24/7 habit and change the way you work. Boston, MA: Harvard Business Review Press.

Petrunko, O. (2010). Dity i media: sotsializatsiia v ahresyvnomu mediaseredovyshchi: monohrafiia [Children and Media: socialization in aggressive media environment: monograph]. Poltava: Ukrpromtorgservice. (in Ukrainian)

Postman, N. (1982). The disappearance of childhood. New York, NY: Delacorte Press.

Prensky, M. (2001). Digital natives, digital immigrants. Part 2: Do they really think di erently? On the Horizon, 9(5), 1-6. doi: 10.1108/10748120110424843.

Przybylski, A. K., Murayama, K., DeHaan, C. R., \& Gladwell, V. (2013). Motivational, emotional, and behavioral correlates of fear of missing out. Computers in Human Behavior, 29(4), 1841-1848. doi: 10.1016/j.chb.2013.02.014.

Romanova, N. F. (2004). Sotsializatsiia ukrainskoho studentstva: ohliad problemy, shliakhy rozviazannia [Socialization of Ukrainian Students: Problem Review and Ways of Solutions]. Ukrainskyi sotsium, 3, 87-92.

Sheiko, V. M. (2001). Kultura. Tsyvilizatsiia. Hlobalizatsiia (kinets XIX - pochatok XXI st.): monohrafiia [Culture. Civilization. Globalization (end of XIX - beginning of XXI centuries): monograph]. Kharkiv: Osnova. (in Ukrainian)

Sheiko, V. M. (2011). Kultura Ukrainy v hlobalizatsiino-tsyvilizatsiinomu vymiri (istorykometodolohichni aspekty): monohrafiia [Culture of Ukraine in Globalizational and Civilizational Dimensions (historical and methodological apects): monograph]. Kyiv: In-t kulturolohii Nats. akad. mystetstv Ukrainy. (in Ukrainian)

Simpson, A. R. (2001). Raising teens: A synthesis of research and a foundation for action. Boston, MA: Center for Health Communication, Harvard School of Public Health. 
Smith, S. L., Choueiti, M., \& Pieper, K. (2015). Inequality in 700 popular films: Examining portrayals of gender, race, \& LGBT status from 2007 to 2014. Los Angeles, CA: USC Annenberg.

Soshchenko, I. G. (2007). Obraz cheloveka $v$ sociokul'turnom prostranstve informacionnogo obshchestva [Man's Image in Social and Cultural Space of Informational Society] (PhD Thesis). Stavropol'.

Stepanov, V. Yu. (2010). Kontseptualni zasady formuvannia ta rozvytku informatsiinoho suspilstva: derzhavno-upravlinskyi aspekt: monohrafiia [Conceptual Foundations of Formation and Development of Informational Society: state and administrative aspect: monograph]. Kharkiv: S.A.M. (in Ukrainian)

Stieger, S., Burger, C., Bohn, M., \& Voracek, M. (2013). Who commits virtual identity suicide? Differences in privacy concerns, Internet addiction, and personality between Facebook users and quitters. Cyberpsychology, Behavior and Social Networking, 16(9), 629-634. doi: 10.1089/cyber.2012.0323.

Tadaieva, A. V. (2016). Sotsialno-pedahohichnyi suprovid sotsializatsii molodshykh shkoliariv u suchasnomu informatsiinomu prostori [Social and Pedagogical Escort of Socialization of Primary Schoolchildren in Modern Informational Space] (PhD Thesis). Starobilsk: Taras Shevchenko National University of Luhansk.

Turkle, S. (2011). Alone together: Why we expect more from technology and less from each other. New York, NY: Basic Books.

Zelenov, Ye. A., Stiopina, O. G. (2010). Vykhovannia studentskoi molodi v umovakh hlobalizatsii: monohrafiia [Students' Upbringing in Conditions of Globalization: monograph]. Luhansk: SNU im. V. Dalia. (in Ukrainian)

Zhilkin, V. V. (2007). Infosocializaciya: sushchnost' ponyatiya [Infosocialization: essence of the notion]. Obshchestvo. Sreda. Razvitie (Terra Humana),1, 40-41. 